\section{Cureus}

Received 09/18/2017

Review began 05/07/2018

Review ended 09/28/2018

Published 10/03/2018

\section{(c) Copyright 2018}

Zhou et al. This is an open access article distributed under the terms of the Creative Commons Attribution License CC-BY 3.0., which permits unrestricted use, distribution, and reproduction in any medium, provided the original author and source are credited.

\title{
Breast Squamous Cell Carcinoma Following Breast Augmentation
}

\author{
Yu M. Zhou ${ }^{1}$, Huma E. Chaudhry ${ }^{2}$, Amar Shah ${ }^{3}$, Janna Andrews ${ }^{4}$ \\ 1. Radiation Oncology, University of Cincinnati College of Medicine, Cincinnati, USA 2. Radiation \\ Oncology, Hofstra Northwell School of Medicine, Hempstead, USA 3. Radiology, Hofstra Northwell \\ School of Medicine, Hempstead, USA 4. Radiation Oncology, Northwell Health, Sleepy Hollow, USA
}

$\square$ Corresponding author: Janna Andrews, jandrews3@northwell.edu

Disclosures can be found in Additional Information at the end of the article

\section{Abstract}

Breast augmentation is the most common cosmetic surgery in the United States. Squamous cell carcinoma (SCC) of the breast raises suspicion of possibly metastatic origin. Here, we report an unusual case of implant-associated SCC of the breast post silicone gel breast implant. The patient is a 46-year-old female with SCC of the breast. She initially had silicone gel breast implantation for breast augmentation in 1995. She had multiple revisions due to swelling and hardening. In 2016, she underwent bilateral prosthesis explantation and bilateral capsulectomy. The pathology demonstrated a 4-cm tumor that was moderately differentiated invasive SCC. On slide review, it was noted that there was squamous epithelization of the implant capsule with benign squamous epithelium on both sides. She received external beam radiation to the right breast; no adjuvant chemotherapy was offered due to the rare histology and paucity of data. Follow-up within a year showed metastasis to the liver, lungs and retroperitoneum. She was admitted and ultimately transferred from the medical intensive care unit to the palliative care unit for comfort care. She expired of her disease in July 2017.

Categories: Plastic Surgery, Radiation Oncology

Keywords: squamous cell carcinoma, breast implant related problems/revisions

\section{Introduction}

Breast augmentation is the most common cosmetic surgery in the United States. While local complications and reoperations are common, it is rare for silicone implants to be associated with conventional carcinoma [1]. Primary squamous cell carcinoma (SCC) of the breast is a rare and generally aggressive disease, representing less than $0.1 \%$ of invasive breast carcinomas [2]. SCC of the breast raises suspicion of possibly metastatic origin. Here, we report an unusual case of implant-associated SCC of the breast post silicone gel breast implant capsule.

\section{Case Presentation}

The patient is a 46-year-old female with SCC of the breast. She initially had silicone gel breast implantation for breast augmentation in 1995. The implantation was surgically revised in 2002 and 2006. In 2014 she noticed hardening and swelling of her right breast. Because of the death of her husband, she did not seek immediate medical attention. She continued to have swelling and increased pain in the right breast. Magnetic resonance imaging (MRI) performed in January 2016 showed a large fluid collection surrounding the intact right silicone implant as shown in Figure 1 . The case was managed by surgical drainage of fluid collection and capsulectomy. In February 2016, she underwent bilateral prosthesis explantation and bilateral capsulectomy. The pathology demonstrated a 4-cm moderately differentiated invasive SCC. It extended into the 


\section{Cureus}

muscle, and in situ tumor was noted to extend to the peripheral margin. There was no perineural or lymphovascular invasion. Pathology of the left breast capsule showed chronic inflammation. Computed tomography (CT) of chest, abdomen and pelvis on February 2016 revealed absence of metastatic disease. The patient underwent re-excision of the remaining chest wall mass in March 2016. Pathology showed well differentiated SCC with negative margins. Chest wall fluid was negative for malignant cells. On slide review, it was noted that there was squamous epithelialization of the implant capsule with benign squamous epithelium on both sides. This indicated that the tumor is likely SCC of the implant capsule rather than primary SCC of the breast. Estrogen and progesterone receptor markers were negative as well. Afterwards, she received external beam radiation. She was treated with radiation while supine with free breathing. Four tangent beams were used to target the right breast with 50 Gray in 25 fractions, followed by a 10 Gray boost to the tumor bed delivered in five fractions. Radiation was delivered using opposed tangents completed in May 2016. No adjuvant chemotherapy was offered due to the rare histology and paucity of data. She followed up in clinic in June 2016 without complications or clinical recurrence.

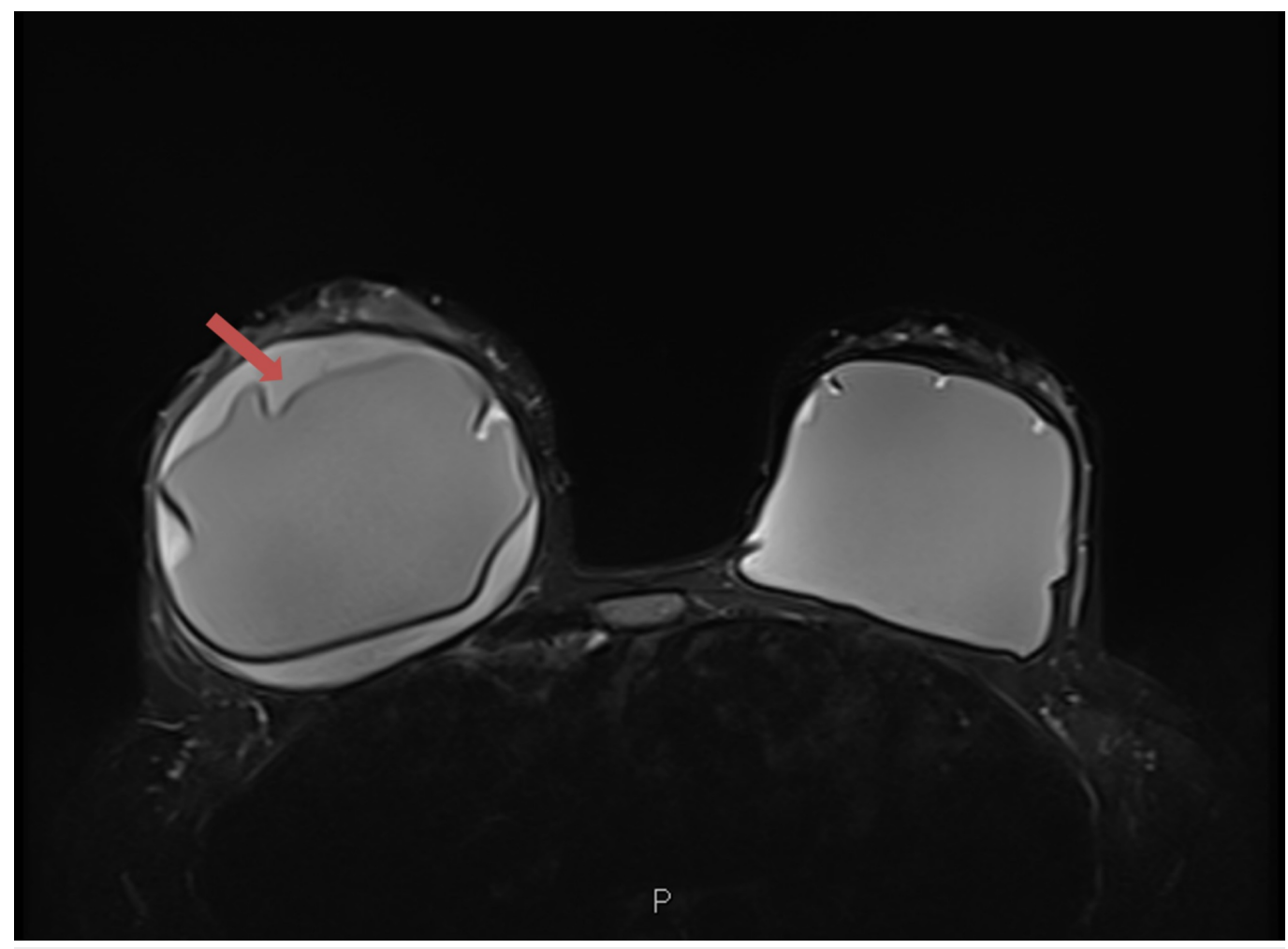

FIGURE 1: Bilateral breast magnetic resonance imaging (MRI).

There is a large fluid collection, indicated by the red arrow, surrounding the intact right silicone implant. The fluid is interposed between the fibrous capsule and the implant.

Follow-up CT scan performed in August 2016 displayed a right upper lobe lung nodule and findings were suspicious for local recurrence (Figure 2). She underwent right video thoracoscopy and right upper lobe wedge resection. The pathology was consistent with metastatic moderately differentiated SCC. The patient declined chemotherapy at this time. CT chest and abdomen at another hospital showed new cavitary lung nodules and right renal and psoas abscess. In February 2017, retroperitoneal fine needle aspiration of the right renal collection was positive for SCC. In June 2017, she was admitted to the hospital for abdominal pain and was found to have progressive disease. CT abdomen and pelvis with intravenous and oral contrast on 6/16/17 demonstrated a $6.1 \mathrm{~cm}$ x $5.7 \mathrm{~cm}$ heterogeneous lesion in the right 


\section{Cureus}

kidney lower pole with invasion into the adjacent right psoas muscle (Figure 3). Progressive metastases to the liver, lungs and retroperitoneum were noted as well. Ultrasound-guided fineneedle aspiration and core biopsy of the liver was positive for metastatic SCC with keratinization and necrosis.

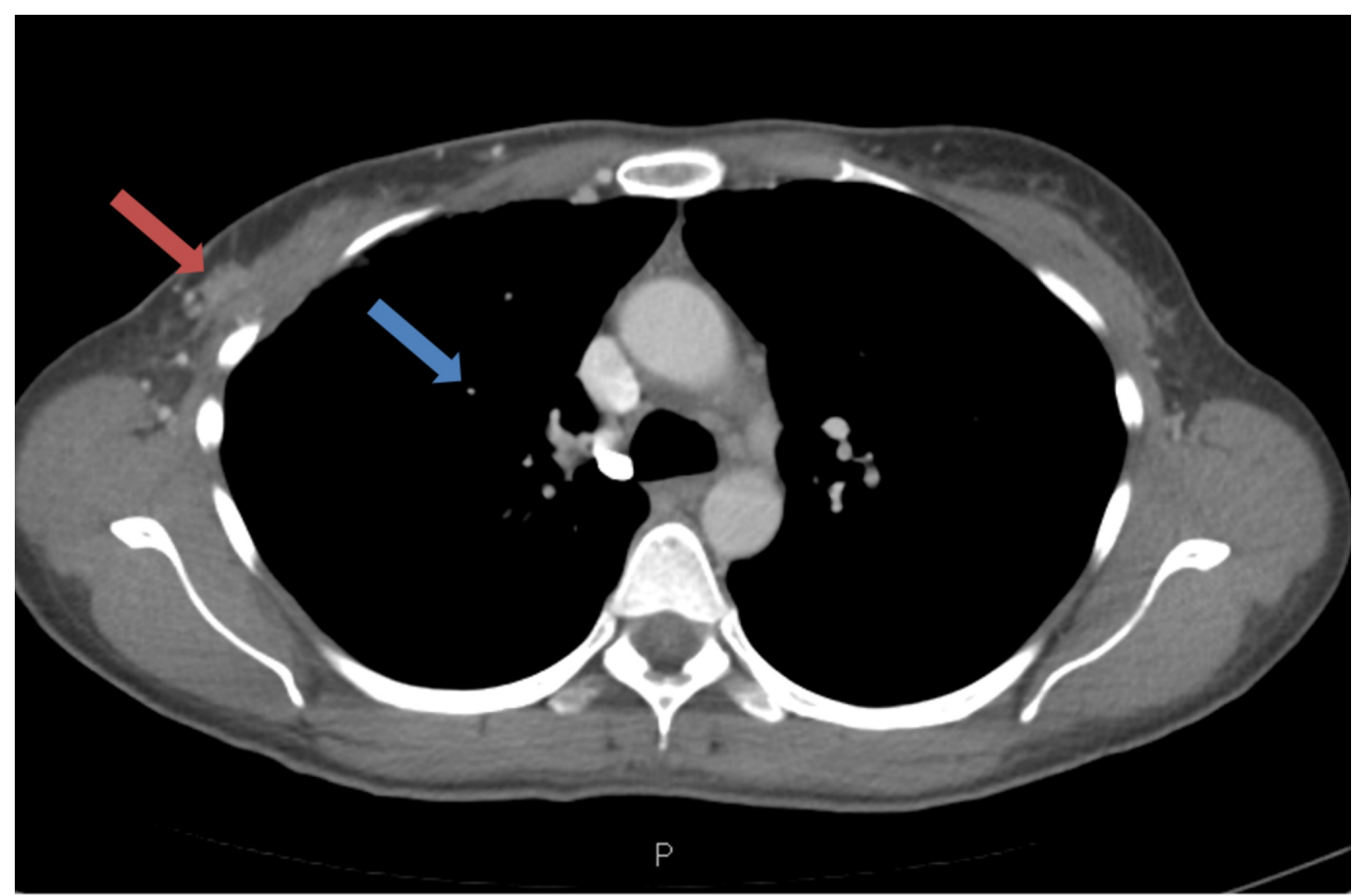

FIGURE 2: Computed tomography (CT) of the chest with intravenous and oral contrast.

CT of the chest showing 1) $8 \mathrm{~mm}$ right upper lobe nodule suspicious for metastatic disease and 2) 6 $x 12 \mathrm{~mm}$ enhancing area in lateral aspect of right breast which may be residual or recurrent disease.

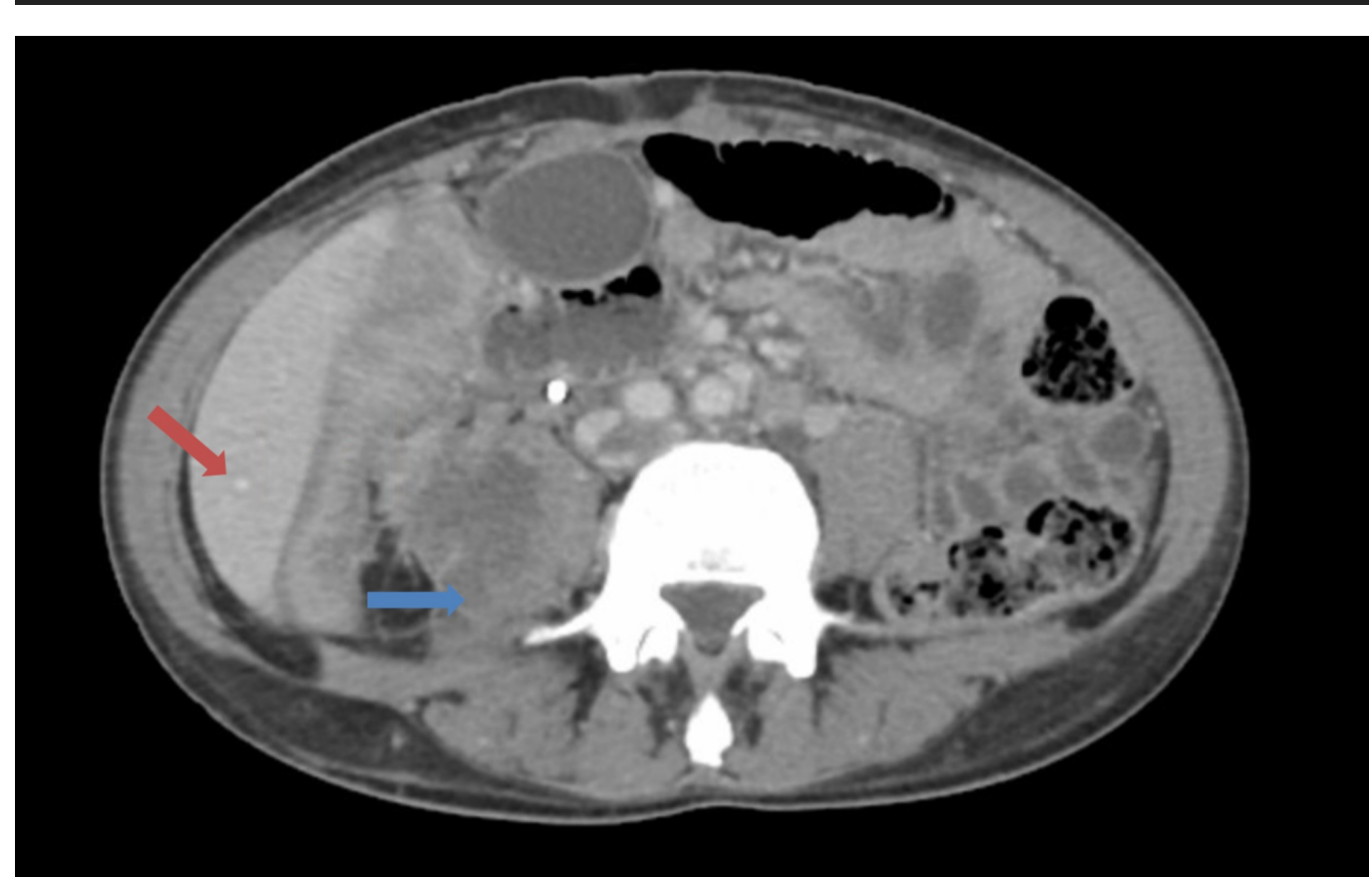




\section{FIGURE 3: Computed tomography (CT) of abdomen showing multiple metastasis.}

CT image showing 1) multiple new hepatic lesions, likely metastases (red arrow) and 2) heterogeneous lesion involving the lower pole of the right kidney with extension into the right psoas muscle (blue arrow).

Her hospital course was complicated by non-ST elevation myocardial infarction, recurrent anemia requiring transfusions, atrial fibrillation with rapid ventricular rate and hypotension. She was noted to have leptomeningeal spread. She was ultimately transferred from the medical intensive care unit to the palliative care unit for comfort care. She expired of her disease in July 2017, one year after her initial diagnosis of cancer.

\section{Discussion}

Squamous cell carcinoma of the breast is a rare diagnosis. Data from the National Cancer Institute's Surveillance, Epidemiology and End Results Registry showed a total of 445 cases between the year 1998 and 2013, with age adjusted incidence of 0.62 per 1,000,000 per year [3]. From the registry, majority of the patients were triple negative for breast markers. Over half of the patients underwent mastectomy and one-third of the cases received radiation. The five-year cause-specific survival was $63.5 \%$.

The available literature shows only five cases of SCC arising from breast implant surrounding capsular tissue [4-7]. In the reported cases as well as in the current patient, there is a remote history of breast augmentation ( $>15$ years) with silicone breast implants as shown in Table 1 . All patients had an insidious onset of breast pain and many initially were misdiagnosed. Since three out of the four patients in the literature with recorded follow-up had multiple metastatic disease within two years, this may suggest the aggressive course of the tumor and an inadequacy of local control. The presence of widespread multiple metastases post-surgery and radiation highlights the importance of incorporating systemic therapy. Early diagnosis may be the key to improving disease-specific survival. In previously reported cases, most patients underwent negative sentinel lymph node biopsies. The observation that some patients deteriorated rapidly may suggest a more aggressive hematogenous metastasis mechanism which is more consistent with SCCs. 


\section{Cureus}

\begin{tabular}{|c|c|c|c|c|c|c|}
\hline & $\begin{array}{l}\text { Paletta et al. } \\
\text { (1992) [4] }\end{array}$ & $\begin{array}{l}\text { Satgunaseelan } \\
\text { et al. (2014) [5] }\end{array}$ & $\begin{array}{l}\text { Zomerlei et } \\
\text { al. (2015) [6] }\end{array}$ & $\begin{array}{l}\text { Olsen et al. } \\
(2017)[7]\end{array}$ & $\begin{array}{l}\text { Olsen et al. } \\
\text { (2017) [7] }\end{array}$ & $\begin{array}{l}\text { Zhou et al. } \\
\text { (2017) }\end{array}$ \\
\hline $\begin{array}{l}\text { Age at } \\
\text { diagnosis } \\
\text { (years) }\end{array}$ & 52 & 58 & 58 & 56 & 81 & 46 \\
\hline $\begin{array}{l}\text { Time of initial } \\
\text { implant }\end{array}$ & 1970s & 1985 & 1980s & 1984 & 1970s & 1995 \\
\hline $\begin{array}{l}\text { Initial onset of } \\
\text { symptoms }\end{array}$ & $\begin{array}{l}\text { 1992: pain } \\
\text { and } \\
\text { induration }\end{array}$ & $\begin{array}{l}\text { 2014: pain and } \\
\text { induration }\end{array}$ & $\begin{array}{l}\text { 2015: pain } \\
\text { and } \\
\text { induration }\end{array}$ & $\begin{array}{l}\text { 2012: pain and } \\
\text { induration }\end{array}$ & $\begin{array}{l}\text { 2012: pain and } \\
\text { induration }\end{array}$ & $\begin{array}{l}\text { 2014: pain and } \\
\text { induration }\end{array}$ \\
\hline Pathology & $\begin{array}{l}\text { Moderately } \\
\text { differentiated } \\
\text { SCC }\end{array}$ & $\begin{array}{l}\text { High grade } \\
\text { SCC }\end{array}$ & $\begin{array}{l}\text { Well } \\
\text { differentiated } \\
\text { SCC* }^{*}\end{array}$ & $\begin{array}{l}\text { Well- } \\
\text { moderately } \\
\text { differentiated } \\
\text { SCC* }^{*}\end{array}$ & $\begin{array}{l}\text { Well- } \\
\text { moderately } \\
\text { differentiated } \\
\text { SCC }^{*}\end{array}$ & $\begin{array}{l}\text { Well- } \\
\text { moderately } \\
\text { differentiated } \\
\text { SCC* }^{*}\end{array}$ \\
\hline $\begin{array}{l}\text { Hormone } \\
\text { status: ER, PR, } \\
\text { Her2/neu }\end{array}$ & NR & NR & $\begin{array}{l}\text { Triple } \\
\text { negative }\end{array}$ & Triple negative & Triple negative & Triple negative \\
\hline $\begin{array}{l}\text { Sentinel lymph } \\
\text { nodal status }\end{array}$ & NR & NR & Negative & Negative & Negative & Negative \\
\hline Management & Mastectomy & Mastectomy & $\begin{array}{l}\text { Bilateral } \\
\text { mastectomies }\end{array}$ & $\begin{array}{l}\text { Mastectomy } \\
\text { then CRT }\end{array}$ & $\begin{array}{l}\text { Mastectomy } \\
\text { then CRT }\end{array}$ & $\begin{array}{l}\text { Excision and } \\
\text { radiation }\end{array}$ \\
\hline Follow up & $\begin{array}{l}\text { No evidence } \\
\text { of disease }\end{array}$ & NR & NR & $\begin{array}{l}\text { Multiple } \\
\text { metastasis }\end{array}$ & $\begin{array}{l}\text { Multiple } \\
\text { metastasis }\end{array}$ & $\begin{array}{l}\text { Multiple } \\
\text { metastasis }\end{array}$ \\
\hline $\begin{array}{l}\text { Follow up } \\
\text { duration }\end{array}$ & One year & NR & NR & Two years & One year & One year \\
\hline
\end{tabular}

\section{TABLE 1: Comparison of case studies.}

Comparison of presentation, pathology and outcomes of breast implant associated SCC [4-7].

CRT: Chemoradiation; *: Pathology associated with implant capsule; NR: Not reported; SCC: Squamous cell carcinoma.

According to the World Health Organization (WHO) classifications of breast tumors, diagnosis of primary squamous cell carcinoma requires: (1) more than $90 \%$ of the malignant cells must have squamous differentiation, (2) there are no other primary sites of SCC, and (3) the lesion must be separate from the skin and nipple [8]. In all cases, the patient had no clinical or radiologic evidence of primary SCC of the breast or cutaneous or distant invasive SCC, as such the reported cases have met these criteria. As with most SCC, the tumors were negative for breast markers, suggesting that these tumors are resistant to hormone treatments.

In this paper, we present a rare case of SCC of the breast with a rare mechanism of onset. Our patient had no evidence of primary mammary carcinoma or SCC from other sites. Pathology report on initial excision of the tumor supports the origin of the tumor as squamous 
epithelialized implant capsule. However, the source of the epithelial cancer is unclear. Multiple case studies, in addition to the previous discussed case reports, have suggested silicone placement can lead to metaplastic squamous epithelium which may be a precursor to SCC [9]. Metaplasia can occur in general post-surgically with presence of chronic inflammation such as Marjolin's ulcers [10]. Although the patient's left breast did not reveal any dysplasia, pathologic analysis did show signs of chronic inflammation. The findings in the non-cancerous left breast suggest a chronic inflammatory process which may take 10 to 20 years for epithelial to turn dysplastic. However, the source of the epithelial cancer remains unknown.

Our patient's course of rapid hematological spread highlights both the aggressive nature of disease and its poor prognosis. Given the aggressiveness of the disease, there may be a need for a different screening protocol for patients with breast implants. There is a difference in outcomes in our comparison of the case studies. Olsen et al. were the first to report a rapid progression of the disease with poor prognosis. In other reported cases, follow-ups were either not reported or showed no disease progression. The dichotomy of outcomes shows the need for close follow-up to better understand the disease.

\section{Conclusions}

There should be a high index of suspicion for SCC of the breast in patients with a history of breast implants, multiple post-implant complications and insidious onset of breast pain and induration. If the diagnosis of SCC is confirmed, aggressive systemic therapy may be needed to improve future outcomes.

\section{Additional Information \\ Disclosures}

Human subjects: Consent was obtained by all participants in this study. Conflicts of interest: In compliance with the ICMJE uniform disclosure form, all authors declare the following: Payment/services info: All authors have declared that no financial support was received from any organization for the submitted work. Financial relationships: All authors have declared that they have no financial relationships at present or within the previous three years with any organizations that might have an interest in the submitted work. Other relationships: All authors have declared that there are no other relationships or activities that could appear to have influenced the submitted work.

\section{References}

1. Handel N, Cordray T, Gutierrez J, Jensen JA: A long-term study of outcomes, complications, and patient satisfaction with breast implants. Plast Reconstr Surg. 2006, 117:757-767. 10.1097/01.prs.0000201457.00772.1d

2. Rosen PP, Hoda SA, Brogi E, Koerner FC: Rosen's Breast Pathology. Wolters Kluwer, Philadelphia; 2014.

3. Yadav S, Yadav D, Zakalik D: Squamous cell carcinoma of the breast in the United States: incidence, demographics, tumor characteristics, and survival. Breast Cancer Res Treat. 2017, 164:201-208. 10.1007/s10549-017-4251-3

4. Paletta C, Paletta FX Jr, Paletta FX Sr: Squamous cell carcinoma following breast augmentation. Ann Plast Surg. 1992, 29:425-429.

5. Satgunaseelan L, Cheung D, Reddy J: Breast implant-associated squamous cell carcinoma - a rare long term complication. Pathology. 2015, 47:72-73. 10.1097/01.PAT.0000461520.64127.87

6. Zomerlei TA, Samarghandi A, Terando AM: Primary squamous cell carcinoma arising from a breast implant capsule. Plast Reconstr Surg Glob Open. 2015, 3:586. 10.1097/GOX.0000000000000567

7. Olsen DL, Keeney GL, Chen B, Visscher DW, Carter JM: Breast implant capsule-associated 


\section{Cureus}

squamous cell carcinoma: a report of 2 cases. Hum Pathol. 2017, 67:94-100.

10.1016/j.humpath.2017.07.011

8. Lakhani SR: WHO classification of tumours of the breast: [views of a working group that convened for a consensus and editorial meeting at the International Agency for Research on Cancer]. International Agency for Research on Cancer. World Health Organization, Lyon; 2012. 1:430

9. Smith LF, Smith TT, Yeary E, McGee JM, Malnar K: Squamous cell carcinoma of the breast following silicone injection of the breasts. J Okla State Med Assoc. 1999, 92:126-130.

10. Barr LH, Menard JW: Marjolin's ulcer. The LSU experience . Cancer. 1983, 52:173-175.

10.1002/1097-0142(19830701)52:1<173::AID-CNCR2820520131>3.0.CO;2-6 